\title{
Comparing functional traits and abundance of invasive versus native woodwasps
}

\author{
Ann E. Hajek', Jacob C. Henry ${ }^{1,3}$, Christopher R. Standley ${ }^{2,4}$, \\ Christopher J. Foelker ${ }^{2,5}$
}

I Department of Entomology, Cornell University, Ithaca, New York, USA 14853-2601 2 Department of Environmental and Forest Biology, State University of New York, College of Environmental Science and Forestry, Syracuse, New York, USA 132103 Present address: Department of Forestry, Mississippi State University, Starkville, Mississippi, USA 397624 Present address: New York State Department of Environmental Conservation, 21 South Putt Corners Rd., New Paltz, New York, USA 125285 Present address: Wisconsin Department of Agriculture, Trade and Consumer Protection, Madison, Wisconsin, USA 53708

Corresponding author: Ann E. Hajek (aeh4@cornell.edu)

Academic editor: A. Roques | Received 9 July 2017 | Accepted 25 September 2017 | Published 3 November 2017

Citation: Hajek AE, Henry JC, Standley CR, Foelker CJ (2017) Comparing functional traits and abundance of invasive versus native woodwasps. NeoBiota 36: 39-55. https://doi.org/10.3897/neobiota.36.14953

\begin{abstract}
Functional traits are useful for comparing the resource use of invasive and native species, with goals of identifying resource overlap to predict competitive interactions. The invasion of northeastern North America by the woodwasp Sirex noctilio has resulted in competition with the native congeneric Sirex nigricornis for suppressed and weakened pines. We compared sizes of adults, venom glands, fecundity, tree species use, voltinism and abundance of the invasive woodwasp $S$. noctilio with the native $S$. nigricornis in northeastern North American pines. Rearing adults from attacked pines showed that these species used the same tree species but $S$. noctilio were far more abundant, especially with increasing time since establishment. Adults of the invasive $S$. noctilio were larger than $S$. nigricornis, female $S$. noctilio had larger glands carrying phytotoxic venom in relation to body size, average-sized $S$. noctilio females carried more eggs, and S. noctilio developed faster than S. nigricornis. Sirex noctilio was the dominant woodwasp infesting suppressed pines in our study areas. We hypothesize that the future abundance of S. nigricornis could depend in part on the availability of wood for oviposition by this native that is not available or acceptable to the earlier-emerging $S$. noctilio.
\end{abstract}

\section{Keywords}

invasive species, functional traits, Siricidae, wood borers 


\section{Introduction}

A major cause of global change is the pervasive introduction of alien species (Wardle et al. 2011; Simberloff et al. 2013) and the increase in global biotic homogenization is not predicted to diminish any time soon (Seebens et al. 2017). Once established in new locations, alien species with strong impacts can change ecosystems in many ways, including altering the biology and ecology of native competitors. The results from interactions between invasive and native competitors can range between coexistence, survival by differential use of resources that arise occasionally or periodically, and competitive displacement of the native species that can remain at low densities or become extinct (see Boivin et al. 2008).

The nature and extent of ecological impacts of alien species depend on the functional ecology of these species in the context of the structure, diversity, and evolutionary experience of the recipient community (Ricciardi et al. 2013). Evaluation of functional traits of invasives and co-existing natives is one means for understanding the effects of invasions, and especially the extent that an invasive is impacting native communities (Mouillot et al. 2013). Although impacts must be evaluated in the context of communities, functional traits such as rapid exploitation of resources and elevated fecundity have been associated with high-impact invasives (Ricciardi et al. 2013). Invasive species that have the greatest impact have also been suggested as being those introducing novel traits and becoming dominant members of communities (Rodriguez-Cabal et al. 2015; Callaway and Ridenour 2004).

Arthropods constitute the most diverse group of organisms (Pimm et al. 1995) and our understanding of the biologies and ecologies of the majority of native species in native ecosystems is frequently limited for many arthropod species prior to invasions. Yet, invasive arthropods have had and are presently having enormous impacts in forests (Liebhold et al. 1995; Gandhi and Herms 2010). Woodwasps are generally not considered forest pests and relatively little is known about their functional traits, although the aggressive invasive Sirex noctilio is a major exception. Sirex noctilio is not a pest where it is native in Eurasia and North Africa, but has caused economic damage in plantations of exotic pines (Pinus spp.) after introductions in the southern hemisphere (Slippers et al. 2015). Established populations of $S$. noctilio were first reported in northeastern North America in 2004 (Hoebeke et al. 2005) and this invasive now occurs in eight eastern US states (CERIS 2017) and two eastern Canadian provinces (de Groot et al. 2006, CFIA 2009) and it is expected to continue to spread. In the southern and northern hemispheres, $S$. noctilio typically oviposits in suppressed pines (Neumann and Minko 1981, Dodds et al. 2010; Ayres et al. 2014). However, populations can increase and, especially in overstocked stands and during droughts, S. noctilio can kill pines that are considered healthy (Madden 1988). Sirex noctilio kills pines by injecting an obligate symbiotic white rot fungus, Amylostereum areolatum (Ryan and Hurley 2012), and a phytotoxic venom (Bordeaux et al. 2014) in association with laying eggs into trees. Wood-boring $S$. noctilio larvae can only develop if the white rot fungus is present, as it serves as an external rumen for larvae (Thompson et al. 2014). 
The establishment of $S$. noctilio in eastern North America is the first time that this invasive has invaded an area hosting native Pinus and Sirex communities, including the congeneric native pine-specialist $S$. nigricornis which has never been considered a pest in North America. Sirex nigricornis is associated with one of two fungal symbionts: either the same fungal symbiont as S. noctilio (A. areolatum) or Amylostereum chailletii (Hajek et al. 2013; Olatinwo et al. 2013). Sirex nigricornis can co-occur in pines with S. noctilio (Ryan et al. 2012a; Hajek et al. 2013). Most adults of S. nigricornis emerge to mate and oviposit approximately 1-2 months after S. noctilio (Ryan et al. 2012a; Foelker et al. 2016; Suppl. material 1: B). Both species can be highly variable in size which depends on sex, parasitism and larval developmental conditions (Ryan and Hurley 2012; Kroll et al. 2013; Haavik et al. 2016a), but in North American areas of sympatry, $S$. noctilio adults are usually slightly larger and carry more eggs than $S$. nigricornis (Haavik et al. 2016a; AEH and JCH unpublished data). While S. noctilio is more aggressive and can attack healthier trees, both species will oviposit in pines of poor vigor or that are recently dead (see Suppl. material 1: A). The resources needed by these species are ephemeral and often patchily distributed; in agreement, studies have shown that populations of $S$. noctilio are limited by the availability of acceptable pines (Haavik et al. 2016b). To investigate these two Sirex species in pines after establishment of $S$. noctilio, we compared the functional traits of $S$. noctilio and $S$. nigricornis. Here, we compare the sizes of venom glands of these two species in relation to female sizes, and their pine species use and voltinism. Using trees with evidence of $S$. noctilio infestation, we present the relative densities of the two Sirex species across time, beginning three years after the first detection of $S$. noctilio in the northeastern US. Our goal is to compare functional traits between the native and invasive to begin to understand the effects of the $S$. noctilio invasion on native siricid communities.

\section{Materials and methods}

\section{Rearing procedures}

Red pines (Pinus resinosa) and scots pines (Pinus sylvestris) with resin beads characteristic of S. noctilio attack (Dodds et al. 2010) were located from October to December in New York and Pennsylvania. These trees were often suppressed and patchily distributed. In spring, infested trees were felled, areas of trunks with resin beads were cut into bolts, and ends of bolts were coated in sealant (Waxlor, Willamette Valley Company, Eugene, Oregon, USA). For the majority of studies, $70 \mathrm{~cm}$ long bolts were placed in fiber barrels $(91 \mathrm{~cm}$ high $\times 61 \mathrm{~cm}$ diam $)$ covered securely with window screening, in an unheated barn. Once adult wasp emergence began (in early to mid-July), barrels were checked daily for two months and then subsequently 3-4 times per week. Sirex that emerged were placed in $29 \mathrm{ml}$ clear plastic cups at $4^{\circ} \mathrm{C}$. All Sirex emerging were identified using characters described in Schiff et al. (2012). 
To cover the emergence periods for both Sirex species, checking for emergence finished in early November, and, at that time, barrels were completely checked for any additional specimens.

For studies comparing the abundance of Sirex species by tree species, Sirex were reared from $50 \mathrm{~cm}$ long bolts placed in horizontal cardboard rearing tubes. Bolts were spaced from tube sides using nails and were housed at ambient environmental conditions in a screened outdoor insectary. Glass emergence jars were fitted to the tube ends, oriented facing screened windows for a natural photoperiod, and emerging Sirex were collected daily.

\section{Adult size and venom gland measurement}

To quantify the sizes of emerging adults, we followed Madden (1974) and Nahrung (2016) in using the apical width of the prothorax. Measurements were made using digital calipers (Traceable Products, Webster, Texas, USA). Infection with the parasitic nematode Deladenus siricidicola negatively impacts adult size (Kroll et al. 2011; Haavik et al. 2016a), so we diagnosed whether each of the adults being measured was parasitized by these nematodes. Males and females were dissected alive under a dissecting microscope at 10x magnification. The abdomen was removed and cut lengthwise to open it, without damaging the venom glands in females, and presence of nematodes within the abdominal cavity and reproductive tissues was recorded. Eggs from females were counted at $63 \times$ magnification and venom glands were removed and immediately weighed on a microscope cover slip.

To compare sizes of $S$. noctilio adults with $(\mathrm{n}=92)$ and without $(\mathrm{n}=412)$ nematodes, we used randomly selected individuals emerging from barrels in 2012-2014. There were far fewer S. nigricornis emerging during this period and nematode infections were uncommon in $S$. nigricornis, so analyses included only $S$. nigricornis of both sexes without nematodes $(\mathrm{n}=36)$.

To assess weights of venom glands, a total of $51 \mathrm{~S}$. noctilio were randomly selected in 2014-2016 for dissection and 21 of these contained nematodes. Since few female S. nigricornis emerged from rearings from the northeast during 2014-2016, 30 S. nigricornis females from Arkansas and Louisiana that had been caught in panel traps were used for venom gland weights. We were concerned that these $S$. nigricornis from the southeast both had been flying before being trapped and were from a different geographic region. To test the accuracy of using southeastern S. nigricornis as replacements for northeastern $S$. nigricornis, we compared the relationship between numbers of eggs and body size for $S$. nigricornis females collected from traps in the southeastern vs. emerging from wood from the northeastern USA. Southeastern S. nigricornis carried the same number of eggs in relation to prothorax width as $S$. nigricornis emerging from wood in the northeastern US $(\mathrm{t}=-1.10 ; \mathrm{P}=0.2713)$, so we used venom gland weights from southeastern $S$. nigricornis for comparisons. 
Table I. First and second year emergence by Sirex noctilio and Sirex nigricornis.

\begin{tabular}{l|c|c|c|c|c|c}
\hline & Location & $\begin{array}{c}\text { 2 years of } \\
\text { emergence }\end{array}$ & $\begin{array}{c}\text { Total Sirex } \\
\text { emerging }\end{array}$ & $\begin{array}{c}\text { Emergence } \\
\text { year 1 (\%) }\end{array}$ & $\begin{array}{c}\text { Emergence } \\
\text { year 2 (\%) }\end{array}$ & $\begin{array}{c}\text { \% trees with 2nd } \\
\text { year emergence }\end{array}$ \\
\hline $\begin{array}{l}\text { Sirex } \\
\text { nigricornis }\end{array}$ & Warren County, NY & $2013-2014$ & 38 & $44.7 \%$ & $55.3 \%$ & $50.0 \%$ \\
\hline \multirow{2}{*}{$\begin{array}{l}\text { Sirex } \\
\text { noctilio }\end{array}$} & Warren County, NY & $2013-2014$ & 15 & $73.3 \%$ & $26.7 \%$ & $25.0 \%$ \\
\cline { 2 - 7 } & Tioga County, PA & $2014-2015$ & 1056 & $98.5 \%$ & $1.5 \%$ & $39.1 \%$ \\
\cline { 2 - 7 } & Tioga County, PA & $2015-2016$ & 709 & $89.1 \%$ & $10.9 \%$ & $42.9 \%$ \\
\hline
\end{tabular}

\section{Tree species use}

Use of $P$. resinosa versus $P$. sylvestris by $S$. nigricornis and $S$. noctilio was quantified using infested trees in northern New York State, with site information in Foelker et al. (2016; Table 1) (2010: 10 P. resinosa, 12 P. sylvestris; 2011: 22 P. resinosa, 10 P. sylvestris). Trees were harvested from 21 April - 24 May in 2010 and 31 March - 7 May in 2011 and Sirex were reared from trees as described above.

\section{Voltinism}

On 4 June 2013, 12 Sirex-infested P. resinosa were collected from a plantation on River Road, Warren Co., New York (4331'59.7"N 7349'30.8"W). Trees were cut into 219 $70 \mathrm{~cm}$ long bolts and woodwasps were reared as described above, with barrels checked every 1-2 days to collect individuals very soon after emergence; females were never found to be ovipositing when collected this soon after emergence. In November 2013, barrels were thoroughly checked for dead Sirex so that any first year emergers were not mistaken for second-year emergers. Barrels were stored in an unheated barn over the winter and were checked for emergence throughout the 2014 flight season. This procedure was repeated for a third year, through the 2014-2015 winter and 2015 flight season. As a continuation to this study, in Tioga Co., Pennsylvania, in spring 2014 we harvested 23 infested $P$. resinosa and, in spring 2015, 29 P. resinosa. Wood from trees cut in 2014 and 2015 was maintained and emergence was checked for two years.

\section{Densities and co-occurrence of $S$. noctilio and S. nigricornis}

Pines with resin beads indicative of $S$. noctilio attack were harvested in central and northern New York State and north-central Pennsylvania and Sirex were reared from them. Even within the same region, it was rare that the exact same site was sampled more than one year. Pinus resinosa were harvested from plantations in Tioga Co., Pennsylvania yearly, from 2011 and 2013-2015, with 20-30 trees harvested each year. Sirex were also reared from mixtures of $P$. resinosa and $P$. sylvestris from natural 
forests in northern New York State and from mature plantations in central New York State. In 2007 only P. sylvestris was sampled as described in Long et al. (2009). Trees included in analyses were those from which either one or the other or both Sirex species emerged.

\section{Data analysis}

A general linear mixed model with year as a random effect was used to compare sizes of Sirex. To compare body size versus venom gland mass, the significance of difference between slopes was calculated (Cohen et al. 2003). Comparisons of body size across species, sex and nematode parasitism were conducted using mixed models with year as a random effect and least squares means were used for post hoc comparisons (SAS 2014). Because very few $S$. nigricornis were reared that were parasitized by nematodes, comparing body sizes for individuals that were parasitized versus not parasitized was only possible for $S$. noctilio. Tree species use analysis was conducted using a mixed model with $(\ln +1)$-transformed densities by volume of wood for $S$. nigricornis versus S. noctilio (SAS 2014). Sirex species, tree height, tree diameter and tree species were explanatory variables, with tree nested within site and site as random effects. The interaction of Sirex species with tree species was initially included but was removed as it was not significant. Wilcoxon signed ranks tests were used to compare numbers of S. noctilio versus S. nigricornis adults emerging from trees in 2007-2014.

\section{Results}

\section{Trait-based studies: Venom glands and Sirex size}

Weights of venom glands increased with increasing body size (measured as prothorax width) (Fig. 1) but this relationship differed by species. The slope of the regressions of body size against venom gland weight for $S$. nigricornis without nematodes was less steep compared with $S$. noctilio without nematodes $(\mathrm{t}=4.527 ; \mathrm{df}=56 ; \mathrm{P}<0.0001)$; this slope was close to twice as steep for $S$. noctilio compared with $S$. nigricornis. The weight of the venom glands for $S$. nigricornis females without nematodes also was significantly less than for $S$. noctilio with nematodes $(\mathrm{t}=3.3824 ; \mathrm{df}=47 ; \mathrm{P}=0.0015)$. Sirex noctilio parasitism by nematodes did not significantly affect the relationship between the weight of the venom gland and body size, when compared with non-parasitized S. noctilio individuals $(\mathrm{t}=1.1141 ; \mathrm{df}=47 ; \mathrm{P}=0.2709)$.

For collections across 2012-2014, on average non-parasitized S. noctilio females (prothorax width: $3.90+0.83 \mathrm{~mm})$ were larger than $S$. nigricornis females $(2.46+$ $0.35 \mathrm{~mm})(\mathrm{t}=6.27 ; \mathrm{P}<0.0001)$ and non-parasitized $S$. noctilio males $(2.92+0.83$ $\mathrm{mm})$ were larger than $S$. nigricornis males $(2.38+0.56 \mathrm{~mm})(\mathrm{t}=3.00 ; \mathrm{P}=0.0028)$. 
No nematodes
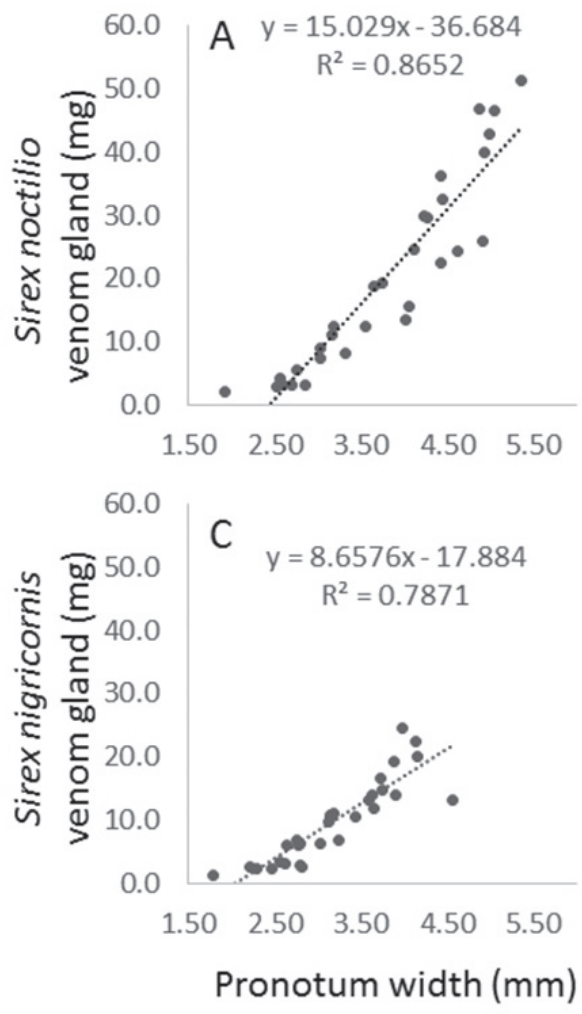

Nematodes

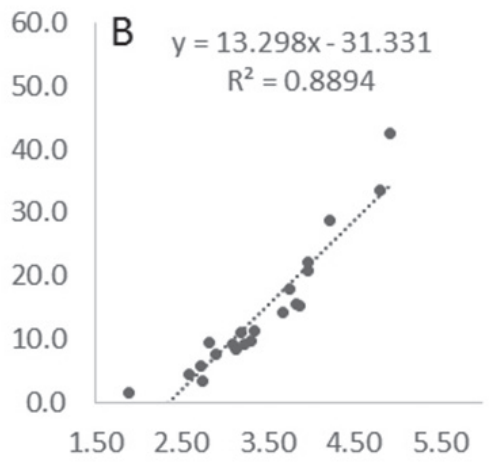

Pronotum width $(\mathrm{mm})$

Figure I. Relationships between venom gland mass and body size, measured as pronotum width, for S. noctilio and S. nigricornis. Sirex noctilio data were analyzed by presence or absence of parasitism by nematodes (Deladenus siricidicola) while numbers of $S$. nigricornis parasitized by nematodes were too low for analysis. A Sirex noctilio females without parasitism by nematodes B $S$. noctilio females parasitized by nematodes, and $\mathbf{C}$ S. nigricornis without nematode parasitism.

For male $S$. noctilio, nematode parasitism unexpectedly resulted in larger body sizes $(\mathrm{t}=-2.62 ; \mathrm{P}=0.0091)$ while this relationship was reversed for females $(\mathrm{t}=2.34$; $\mathrm{P}=0.0195$ ) (Fig. 2).

\section{Trait-based studies: Tree species preference}

Sirex densities by tree species did not differ between the two Sirex species $\left(\mathrm{F}_{1,52.6}=0.01\right.$; $\mathrm{P}=0.9395)$. The only main effect that was significant in the model was the comparison of densities of the two Sirex species $\left(\mathrm{F}_{1,56}=32.11 ; \mathrm{P}<0.0001 ;\right.$ S. nigricornis density $=$ $8.9 \pm 2.6 / \mathrm{m}^{3}, S$. noctilio density $\left.=44.3 \pm 11.5 / \mathrm{m}^{3}\right)$. 


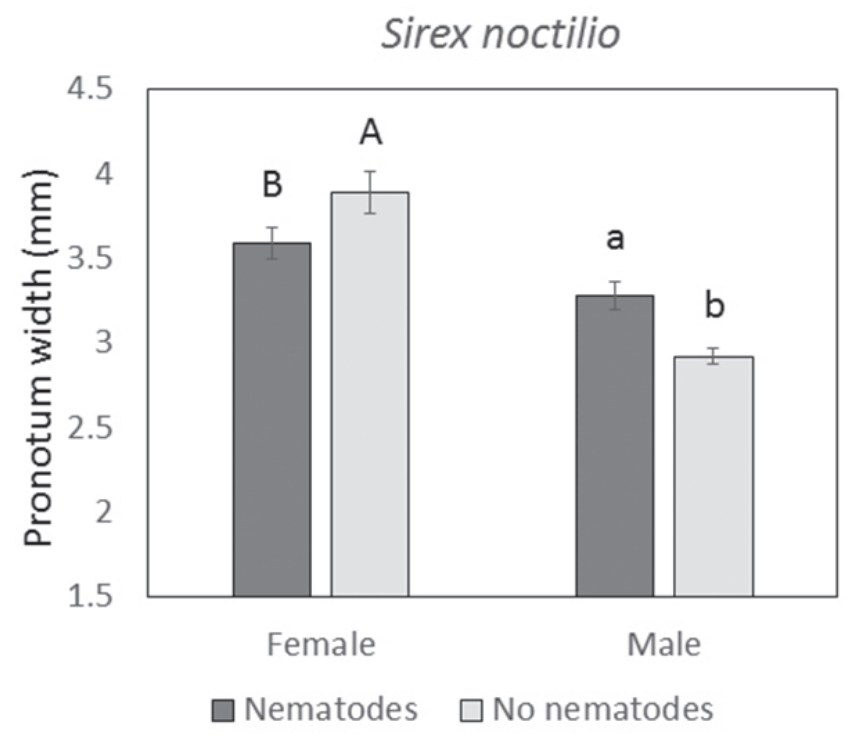

Figure 2. Mean body size (+ SE), measured as pronotum width, for S. noctilio males or females parasitized by the nematode $D$. siricidicola or not. Different letters (comparing either capital letters or comparing lower case letters) demonstrate significant differences within sexes.

\section{Trait-based studies: Comparing voltinism}

Nearly half of adult $S$. nigricornis emerged from wood during the first season in our rearings, over half emerged during year 2 (Table 1), and no S. nigricornis emerged during year 3. In contrast, emergence of $S$. noctilio adults primarily occurred in year 1 (Table 1 ). Numbers of $S$. noctilio emerging from wood in 2013-2014 were low but among these, $26.7 \%$ emerged during the second year. For wood harvested in 2014 or 2015 and reared for two years, from $1.5 \%$ to $10.9 \%$ of the S. noctilio emerged during year 2 .

\section{Densities and co-occurrence of $S$. noctilio and $S$. nigricornis}

Between 2010 and 2015, S. nigricornis densities were lower than densities of S. noctilio in central New York State and north central Pennsylvania, where most pines that were sampled had been purposefully planted (Table 2). However, when sites in central and northern New York State were sampled within 2-3 years of the first reports of S. noctilio in those areas (see Table 2 footnotes), numbers of $S$. nigricornis emerging did not differ significantly from $S$. noctilio, although they were usually numerically lower. When $S$. nigricornis emerged, they more commonly co-occurred in the same trees as S. noctilio and rarely were the only Sirex species emerging from a tree. In 2015, no $S$. nigricornis emerged from infested material from north central Pennsylvania and during this study, densities of $S$. nigricornis from this same area were always low. 


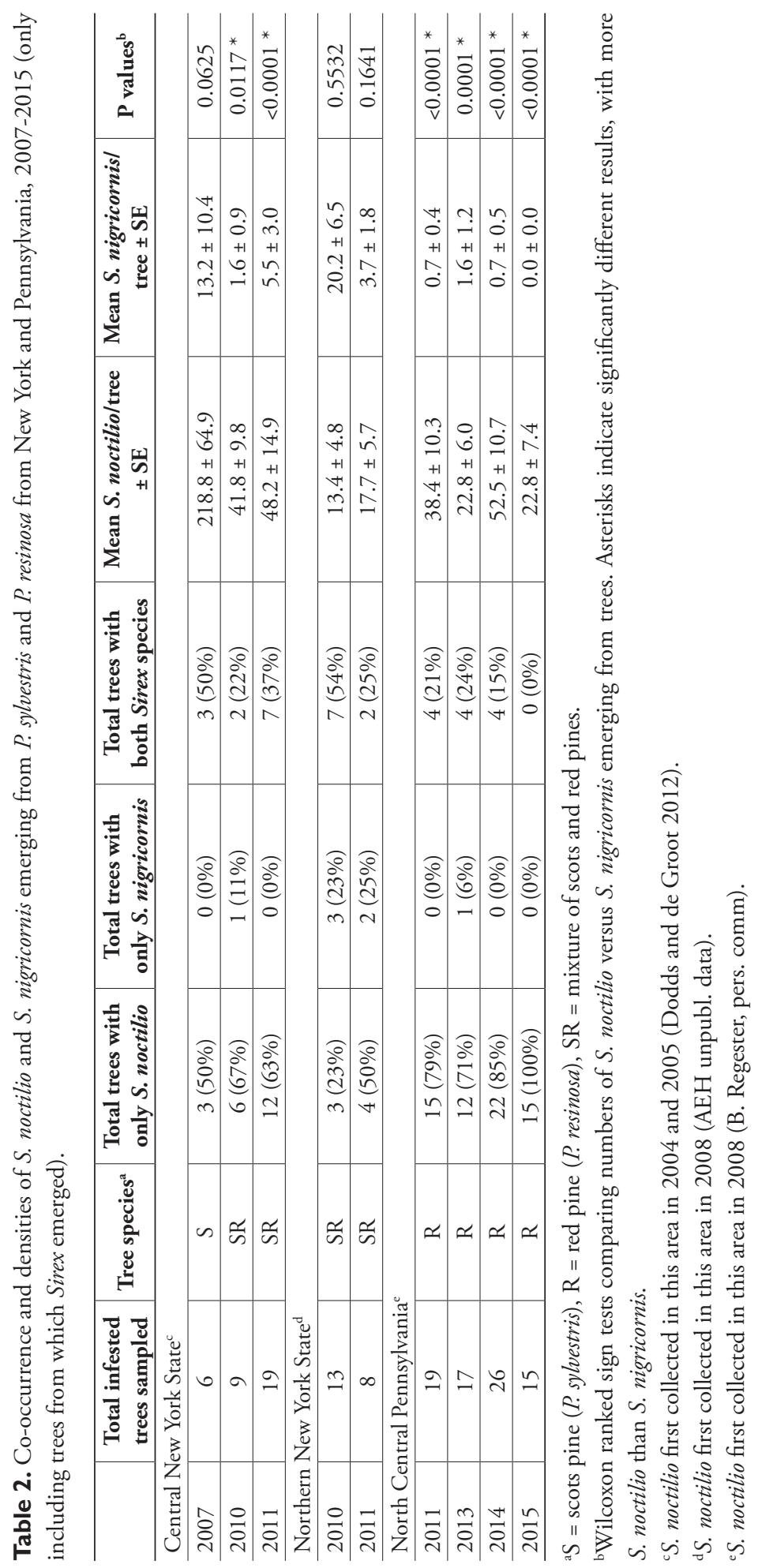




\section{Discussion}

\section{Comparing functional traits}

The overall body sizes of $S$. noctilio as well as the sizes of their venom glands were significantly larger than the bodies and venom glands of the native $S$. nigricornis. The venom glands of $S$. noctilio are also larger than those of seven other European siricids (Spradbery 1977) and experimentation has shown that venom from S. noctilio had greater phytotoxic activity than venom of these European siricids (Spradbery 1973). While a key component of the venom in the $S$. noctilio gland has been characterized as noctilisin (Bordeaux et al. 2014), the identities of compounds in the venom glands of $S$. nigricornis, or glands of any other siricids, are not known (Wang et al. 2016). Regardless, the fact that the $S$. noctilio venom glands are larger (relative to adult body size) than venom glands known from other siricids is consistent with the fact that this is the most aggressive siricid, reported as able to kill relatively healthy pines where it is adventive (see Suppl. material 1: A), while other woodwasps are considered relatively benign secondary pests in forests (Schiff et al. 2012).

Haavik et al. (2016a) found that S. nigricornis carries more eggs per body size than S. noctilio and our studies have documented the same trend (AEH and JCH, unpublished data). However, the present study demonstrated that on average $S$. noctilio females with or without nematode infections were larger than $S$. nigricornis females and the same relationship holds for males. So, although S. nigricornis has the potential to carry more eggs than $S$. noctilio, when we calculated the numbers of eggs per female based on sizes of females that emerged from wood in our studies, using the regression equations in Haavik et al. (2016a), the number of eggs for average-sized S. noctilio female was 166 but 138 eggs would be produced by S. nigricornis. Thus, the larger body size of $S$. noctilio emerging from trees compensated so that on average females of the invasive carried more eggs than $S$. nigricornis. It was unexpected that while nematodeinfected $S$. noctilio females were smaller than healthy females, nematode-infected males were larger than healthy males, an association also found by Haavik et al. (2016a).

The densities of the two Sirex species emerging from P. resinosa and P. sylvestris did not differ by tree species. Studies have found a trend of $P$. sylvestris being colonized more frequently by $S$. noctilio compared with P. resinosa (Dodds et al. 2010; Foelker 2016) and S. nigricornis was not included in those studies. Largely based on the southern hemisphere where many North American pines have been introduced, susceptibility of pine species to S. noctilio varies by tree species (Ryan and Hurley 2012; Nahrung et al. 2015). Our result was somewhat unexpected because P. sylvestris is native to Europe, where it is assumed to have coevolved with $S$. noctilio (Ayres et al. 2014). However, we do not know exactly where the genotypes of $S$. noctilio introduced to New York and Pennsylvania originated and, given the broad native geographic range of $S$. noctilio, it is possible that these genotypes of this woodwasp did not co-evolve with P. sylvestris (Boissin et al. 2012; Bittner et al. 2017). On the other hand, P. resinosa and S. nigricornis co-evolved in North America and in this case there was no preference for the native pine over the introduced pine. 
Sirex noctilio and $S$. nigricornis also differed significantly based on the percentages of the populations emerging from wood after 1 vs 2 years. In our studies, S. noctilio mainly emerged in year 1; from $1.5-27.7 \%$ of $S$. noctilio emerged the second year (Table 2) while in Ontario, Ryan et al. (2012b) found 2.2\% emergence during year 2. Second-year emergence of S. noctilio was $15-25 \%$ in New Zealand and Australia, including Tasmania (Morgan 1968; Taylor, 1978), 1.6\% in Eurasia (Spradbery and Kirk 1978), and 24\% in Galicia, Spain (Lombardero et al. 2016). In all cases, percent emergence for $S$. noctilio in the second year of rearing was less than that recorded for S. nigricornis in our study, for which close to $50 \%$ emergence occurred in both years 1 and 2. Differences in voltinism between $S$. noctilio and $S$. nigricornis could have large impacts on their population dynamics. Based on our results, future studies of $S$. nigricornis, at least in northeastern North America, should allow two years for emergence from infested wood.

\section{Comparing abundance of Sirex species}

In northeastern North America $S$. noctilio is now the most abundant woodwasp attacking pines (Long et al. 2009; Ryan et al. 2012a; Foelker et al. 2016). Unfortunately, there are no records of the population densities or tree use by $S$. nigricornis before $S$. noctilio arrived but now, use of suppressed pines by $S$. nigricornis is much less than use of this resource by $S$. noctilio (e.g., Table 2).

Sirex noctilio has a temporal advantage over S. nigricornis as many emerge 1-2 months before $S$. nigricornis, although there is overlap in emergence between these species in northeastern North America (Ryan et al. 2012a; Haavik et al. 2013; Hartshorn et al. 2016; Suppl. material 1: B). Sirex noctilio is found colonizing trees at higher densities than $S$. nigricornis. Therefore, each year $S$. noctilio will occupy what is considered as being their preferred resources (i.e., suppressed trees that are not yet dead; see Suppl. material 1: A) before $S$. nigricornis adults have emerged. Among all pines from which Sirex were reared, only S. noctilio emerged from 56\% (across the 9 years of this study). However, after the invasive had been present for a few years in an area, when the two species both emerged from trees, numbers of $S$. nigricornis were lower than $S$. noctilio and we very rarely found only $S$. nigricornis emerging from a tree. Based on the low numbers of $S$. nigricornis emerging from infested trees, we hypothesize that population densities of $S$. nigricornis emerging could be low because when adults of the native species emerge, the transient resource of suppressed trees had already mostly been exploited. However, S. nigricornis could have an advantage in situations where pines unacceptable to $S$. noctilio for some reason could be available for use by $S$. nigricornis or when pines could become weakened (e.g., by lightning strikes) after the main flight of $S$. noctilio adults and before or during the $S$. nigricornis flight time. In addition, the fact that the transient resource of suppressed trees are often patchily distributed (e.g., Ayres et al. 2014) could lead to coexistence of these species via differential spatial distribution of use of suppressed pines. 
Monceau et al. (2015) have shown that some degree of niche differentiation between native and invasive hornets can minimize competition. We did not sample recently dead trees in this study but experiments have shown that S. nigricornis will oviposit into wood from trees that have recently been cut, although oviposition was minimal as soon as 30 days after cutting the wood (Hartshorn 2012). We do not know to what extent $S$. noctilio will choose to oviposit in wood from recently cut trees but when siricids were reared from diverse types of wood sampled over eight years from Europe, Turkey and North Africa, S. noctilio only emerged from samples from standing trees and timber and never from fallen trees or wood on the ground (Spradbery and Kirk 1978). While niches of these two Sirex species probably differ to some extent relative to the health or condition of pines that are preferred or acceptable for oviposition and development, there is also niche overlap (see Suppl. material 1: A). Based on relative densities and traits, we hypothesize that after the invasion of $S$. noctilio, $S$. nigricornis could develop in suppressed trees less often than prior to the invasion and the native might now more frequently use recently fallen, dead trees, as $S$. noctilio would have already exploited the majority of standing suppressed pines. Alternatively, suppressed pines further weakened by $S$. noctilio attack could at times provide an increased resource for $S$. nigricornis populations. Knowledge about normal densities of $S$. nigricornis before invasion by $S$. noctilio is necessary to further understand the impact of the native on the invasive woodwasp. In addition, further studies investigating the health of pines associated with oviposition and development of these two Sirex species are needed to clarify the overlap in niches of these two species with regard to tree health.

\section{Conclusions}

In this study, we investigated aspects of the biology and ecology of these now-sympatric native and invasive siricids toward predicting the impact $S$. noctilio might be having on this congeneric native species also utilizing suppressed pines (Suppl. material 1: A). The invasive $S$. noctilio uses the same tree species as the native $S$. nigricornis but venom glands of $S$. noctilio are larger. Although $S$. nigricornis carries more eggs than $S$. noctilio per body size, $S$. nigricornis adults are significantly smaller than $S$. noctilio, resulting in greater fitness for $S$. noctilio. In other systems, fecundity has been shown to be an important functional trait for predicting success of invasives (e.g., Boivin et al. 2008; Capellini et al. 2015). In addition, the phenology of the invasive and its faster speed of development also allow $S$. noctilio to exploit common resources before $S$. nigricornis.

We cannot definitively answer to what extent the presence of $S$. noctilio results in more or less habitat in which $S$. nigricornis can develop. Little is known of the biology and ecology of $S$. nigricornis but we know that it will oviposit and develop in pines already attacked by $S$. noctilio. Attacks by $S$. noctilio could create more suppressed trees acceptable to $S$. nigricornis by pre-injecting the symbiont plus venom and thereby disabling tree defenses and thus creating more habitat for S. nigricornis. However, abundance data suggest that few $S$. nigricornis emerge from trees that they co-inhabit 
with $S$. noctilio. As an alternative, since $S$. noctilio mostly flies and oviposits before $S$. nigricornis, perhaps this invasive attacks the best of the transient resource of weakened trees that could potentially be used by either species and $S$. noctilio thus uses most of this resource before $S$. nigricornis adult females would have emerged to oviposit. The extent that co-occurring $S$. nigricornis and $S$. noctilio will compete for recently dead trees remains to be determined. Further data documenting the ecology and naturally occurring densities of S. nigricornis in the southeastern US, where pine forests are extensive, will assist with predicting to what extent $S$. nigricornis niches and abundance will be altered when $S$. noctilio spreads into this region.

\section{Acknowledgments}

We thank Brad Regester, Bill Laubscher and Tim Marasco, Pennsylvania DCNR Bureau of Forestry for assistance with infested wood from north central Pennsylvania, Jim Meeker, Wood Johnson, Jessica Hartshorn and Fred Stephen for providing S. nigricornis from Louisiana and Arkansas, and USDA APHIS for assistance with obtaining S. noctilio-infested wood in 2007. Francoise Vermeylen assisted with statistical analyses and we thank Flora Krivak-Tetley, David Harris, Stefanie Kroll, and Sandy Liebhold for assistance with this manuscript. This work was supported by USDA Forest Service Cooperative Agreements granted to AEH.

\section{References}

Ayres MP, Pena R, Lombardo JA, Lombardero MJ (2014) Host use patterns by the European woodwasp, Sirex noctilio, in its native and invaded range. PLOS ONE 9: e90321. https:// doi.org/10.1371/journal.pone.0090321

Bittner T, Hajek AE, Haavik L, Allison J, Nahrung H (2017) Multiple introductions of Sirex noctilio (Hymenoptera: Siricidae) in northeastern North America based on microsatellite genotypes, and implications for biological control. Biological Invasions 19: 1431-1447. https://doi.org/10.1007/s10530-016-1365-1

Boivin T, Rouault G, Chalon A, Candau J-N (2008) Differences in life history strategies between an invasive and a competing resident seed predator. Biological Invasions 10: 1013-1025. https://doi.org/10.1007/s10530-007-9180-3

Boissin E, Hurley B, Wingfield MJ, Vasaitis R, Stenlid J, Davis C, de Groot P, Ahumada R, Carnegie A, Goldarazena A, Klasmer P, Wermelinger B, Slippers B (2012) Retracing the routes of introduction of invasive species: the case of the Sirex noctilio woodwasp. Molecular Ecology 21: 5728-5744. https://doi.org/10.1111/mec.12065

Bordeaux JM, Lorenz WW, Johnson D, Badgett MJ, Glushka J, Orlando R, Dean JFD (2014) Noctilisin, a venom glycopeptide of Sirex noctilio (Hymenoptera: Siricidae), causes needle wilt and defense gene responses in pines. Journal of Economic Entomology 107: 1931-1945. https://doi.org/10.1603/EC14151 
Callaway RM, Ridenour WM (2004) Novel weapons: invasive success and the evolution of increased competitive ability. Frontiers in Ecology and the Environment 2: 436-443. https:// doi.org/10.1890/1540-9295(2004)002[0436:NWISAT]2.0.CO;2

Canadian Food Inspection Agency (CFIA) (2009) Plant protection survey report: European wood wasp. http://www.inspection.gc.ca/plants/plant-protection/plant-pestsurveillance/2009-plant-protection-survey-report/eng/1337307704518/1337307793309 [accessed 11 Nov 2015]

Capellini I, Baker J, Allen WL, Street SE, Vendetti C (2015) The role of life history traits in mammalian invasion success. Ecology Letters 18: 1099-1107. https://doi.org/10.1111/ ele. 12493

Center for Environmental and Research Information Systems (CERIS), Purdue University (2017) Survey Status of Sirex woodwasp - Sirex noctilio. http://pest.ceris.purdue.edu/map. php?code=ISBBADA\&year=2017 [accessed 26 May 2017]

Cohen J, Cohen P, West SG, Aiken LS (2003) Applied multiple regression/correlation analysis for the behavioral sciences (3rd edn). Lawrence Earlbaum Associates, Mahwah, NJ.

de Groot P, Nystrom K, Scarr T (2006) Discovery of Sirex noctilio (Hymenoptera: Siricidae) in Ontario, Canada. Great Lakes Entomologist 39(1/2): 49-53.

Dodds KJ, de Groot P (2012) Sirex surveys and management: challenges of having Sirex noctilio in North America. In: Slippers B, de Groot P, Wingfield MJ (Eds) The sirex woodwasp and its fungal symbiont: research and management of a worldwide invasive pest. Springer, Netherlands, 265-286. https://doi.org/10.1007/978-94-007-1960-6_19

Dodds KJ, de Groot P, Orwig DA (2010) The impact of Sirex noctilio in Pinus resinosa and Pinus sylvestris stands in New York and Ontario. Canadian Journal of Forest Research 40: 212-223. https://doi.org/10.1139/X09-181

Foelker CJ (2016) Beneath the bark: associations among Sirex noctilio development, bluestain fungi, and pine host species in North America. Ecological Entomology 41: 676-684. https:// doi.org/10.1111/een.12342

Foelker CJ, Standley CR, Parry D, Fierke MK (2016) Complex ecological relationships among an assemblage of indigenous hymenopteran parasitoids, the exotic European woodwasp (Sirex noctilio; Hymenoptera: Siricidae), and a native congener. The Canadian Entomologist 148: 532-542. doi: https://doi.org/10.4039/tce.2016.6

Gandhi KJ, Herms DA (2010) Direct and indirect effects of alien insect herbivores on ecological processes and interactions in forests of eastern North America. Biological Invasions 12: 389-405. https://doi.org/10.1007/s10530-009-9627-9

Haavik LJ, Meeker JR, Johnson W, Ryan K, Turgeon JJ, Alison JD (2013) Predicting Sirex noctilio F. and S. nigricornis F. (Hymenoptera: Siricidae) emergence using degree-days. Entomologia Experimentalis et Applicata 149: 177-184. https://doi.org/10.1111/eea.12119

Haavik LJ, Allison JD, MacQuarrie CJK, Nott RW, Ryan K, de Groot P, Turgeon JJ (2016a) Nonlethal effects of nematode infection on Sirex noctilio and Sirex nigricornis (Hymenoptera: Siricidae). Environmental Entomology 45: 320-327. https://doi.org/10.1093/ee/nvv223

Haavik LJ, Dodds KJ, Ryan K, Allison JD (2016b) Evidence that the availability of suitable pine limits non-native Sirex noctilio in Ontario. Agricultural and Forest Entomology 18: 357-366. https://doi.org/10.1111/afe.12167 
Hajek AE, Nielsen C, Kepler RM, Long SJ, Castrillo L (2013) Fidelity among Sirex woodwasps and their fungal symbionts. Microbial Ecology 65: 753-762. https://doi.org/10.1007/ s00248-013-0218-z

Hartshorn JA (2012) Effects of felled shortleaf pine (Pinus echinata Mill.) moisture loss on oviposition preferences and survival of Sirex nigricornis F. (Hymenoptera: Siricidae). M.S. thesis, University of Arkansas, Fayetteville.

Hartshorn JA, Haavik LJ, Allison JD, Meeker JR, Johnson W, Galligan LD, Chase KD, Riggins JJ, Stephen FM (2016) Emergence of adult female Sirex nigricornis F. and Sirex noctilio F. (Hymenoptera: Siricidae) coincides with a decrease in daily minimum and maximum temperature. Agricultural and Forest Entomology 18: 206-213. https://doi.org/10.1111/ afe. 12153

Hoebeke ER, Haugen DA, Haack RA (2005) Sirex noctilio: Discovery of a Palearctic siricid woodwasp in New York. Newsletter of the Michigan Entomological Society 50(1-2): 24-25.

Kroll SA, Hajek AE, Morris EE, Long SJ (2013) Parasitism of Sirex noctilio by non-sterilizing Deladenus siricidicola in northeastern North America. Biological Control 67: 203-211. https://doi.org/10.1016/j.biocontrol.2013.08.005

Liebhold AM, MacDonald WL, Bergdahl D, Mastro VC (1995) Invasion by exotic forest pests: a threat to forest ecosystems. Forest Science Monographs 30: 1-49.

Lombardero MJ, Ayres MP, Krivak-Tetley FE, Fitza KNE (2016) Population biology of the European woodwasp, Sirex noctilio, in Galicia, Spain. Bulletin of Entomological Research 106: 569-580. https://doi.org/10.1017/S0007485316000043

Long SJ, Williams DW, Hajek AE (2009) Sirex species (Hymenoptera: Siricidae) and their parasitoids in Pinus sylvestris in eastern North America. The Canadian Entomologist 141: 153-157. https://doi.org/10.4039/n08-068

Madden JL (1974) Oviposition behavior of the woodwasp, Sirex noctilio F. Australian Journal of Zoology 22: 341-351. https://doi.org/10.1071/ZO9740341

Madden JL (1988) Sirex in Australasia. In: Berryman AA (Ed.) Dynamics of forest insect populations. Plenum, New York, 407-429. https://doi.org/10.1007/978-1-4899-0789-9_20

Monceau K, Maher N, Bonnard O, Thiéry D (2015) Evaluation of competition between a native and an invasive hornet species: do seasonal phenologies overlap? Bulletin of Entomological Research 105: 462-469. https://doi.org/10.1017/S0007485315000280

Morgan FD (1968) Bionomics of Siricidae. Annual Review of Entomology 13: 239-256. https://doi.org/10.1146/annurev.en.13.010168.001323

Mouillot D, Graham NAJ, Villéger S, Mason NWH, Bellwood DR (2013) A functional approach reveals community responses to disturbances. Trends in Ecology \& Evolution 28: 168-177. http://dx.doi.org/10.1016/j.tree.2012.10.004

Nahrung HF (2016) Sirex woodwasp Sirex noctilio (Hymenoptera: Siricidae): revisiting some past perceptions. Austral Entomology 56: 148-152. https://doi.org/10.1111/aen.12217

Nahrung HF, Ramsden M, Griffiths M (2015) Sirex woodwasp range expansion in Australia: performance and parasitism on two commercial pine species. Forestry (London) 89: 310-315. https://doi.org/10.1093/forestry/cpv039

Neumann FG, Minko G (1981) The Sirex wood wasp in Australian radiata pine plantations. Australian Forestry 44: 46-63. https://doi.org/10.1080/00049158.1981.10674289 
Olatinwo R, Allison J, Meeker J, Johnson W, Streett D, Aime MC, Carlton C (2013) Detection and identification of Amylostereum areolatum (Russulales: Amylostereaceae) in the mycangia of Sirex nigricornis (Hymenoptera: Siricidae) in central Louisiana. Environmental Entomology 42: 1246-1256. http://dx.doi.org/10.1603/EN13103

Pimm SL, Russell GJ, Gittleman JL, Brooks TM (1995) The future of biodiversity. Science 269: 347. https://doi.org/10.1126/science.269.5222.347

Ricciardi A, Hoopes MF, Marchetti MP, Lockwood JL (2013) Progress toward understanding the ecological impacts of nonnative species. Ecological Monographs 83: 263-282. https:// doi.org/10.1890/13-0183.1

Rodriguez-Cabal MA, Gibbons TC, Schulte PM, Barrios-Garcia NM, Crutsinger GM (2015) Comparing functional similarity between a native and an alien slug in temperate rain forests of British Columbia. Neobiota 25: 1-14. https://doi.org/10.3897/neobiota.25.8316

Ryan K, Hurley BP (2012) Life history and biology of Sirex noctilio. In: Slippers B, de Groot P, Wingfield MJ (Eds) The sirex woodwasp and its fungal symbiont: research and management of a worldwide invasive pest. Springer, Netherlands, 15-30. https://doi.org/10.1007/97894-007-1960-6_2

Ryan K, de Groot P, Nott RW, Drabble S, Ochoa I, Davis C, Smith SM, Turgeon JJ (2012a) Natural enemies associated with Sirex noctilio (Hymenoptera: Siricidae) and S. nigricornis in Ontario, Canada. Environmental Entomology 41: 289-297. http://dx.doi.org/10.1603/ EN11275

Ryan K, de Groot P, Smith SM (2012b) Evidence of interaction between Sirex noctilio and other species inhabiting the bole of Pinus. Agricultural and Forest Entomology 14: 187-195. https://doi.org/10.1111/j.1461-9563.2011.00558.x

SAS (2014) Statistical analysis software, 9.4. SAS Institute Inc., Cary, North Carolina.

Schiff NM, Goulet H, Smith DR, Boudreault C, Wilson AD, Scheffler BE (2012) Siricidae (Hymenoptera: Symphyta: Siricoidea) of the Western Hemisphere. Canadian Journal of Arthropod Identification 29: 1-305. https://doi.org/10.3752/cjai.2012.21

Seebens H, Blackburn TM, Dyer EE, Genovesi P, Hulme PE, Jeschke JM, Pagad S, Pyšek P, Winter M, Arianoutsou M, et al. (2017) No saturation in the accumulation of alien species worldwide. Nature Communications 8: 14435. https://doi.org/10.1038/ncomms14435

Simberloff D, Martin J-L, Genovesi P, Maris V, Wardle DA, Aronson J, Courchamp F, Galil B, Garcì-Berthou E, Pascal M, Pyšek P, Sousa R, Tabacchi E, Vilà M (2013) Impacts of biological invasions: what's what and the way forward. Trends in Ecology \& Evolution 28: 58-66. https://doi.org/10.1016/j.tree.2012.07.013

Slippers B, Hurley BP, Wingfield MJ (2015) Sirex woodwasp: A model for evolving management paradigms of invasive forest pests. Annual Review of Entomology 60: 601-619. https://doi.org/10.1146/annurev-ento-010814-021118

Spradbery JP (1973) A comparative study of the phytotoxic effects of siricid woodwasps on conifers. Annals of Applied Biology 75: 309-320. https://doi.org/10.1111/j.1744-7348.1973. tb07980.x

Spradbery JP (1977) The oviposition biology of siricid woodwasps in Europe. Ecological Entomology 2: 225-230. https://doi.org/10.1111/j.1365-2311.1977.tb00885.x 
Spradbery JP, Kirk AA (1978) Aspects of the ecology of siricid woodwasps (Hymenoptera: Siricidae) in Europe, North Africa and Turkey with special reference to the biological control of Sirex noctilio F. in Australia. Bulletin of Entomological Research 68: 341-359. https://doi.org/10.1017/S0007485300009330

Taylor KL (1978) Evaluation of the insect parasitoids of Sirex noctilio (Hymenoptera: Siricidae) in Tasmania. Oecologia 32: 1-10. https://doi.org/10.1007/BF00344686

Thompson BM, Bodart J, McEwen C, Gruner DS (2014) Adaptations for symbiont-mediated external digestion in Sirex noctilio (Hymenoptera: Siricidae). Annals of the Entomological Society of America 107: 453-460. http://dx.doi.org/10.1603/AN13128

Wang T, Zhao M, Rotgans BA, Ni G, Dean JF, Nahrung HF, Cummins SF (2016) Proteomic analysis of the venom and venom sac of the woodwasp, Sirex noctilio-Towards understanding its biological impact. Journal of Proteomics 146: 195-206. https://doi.org/10.1016/j. jprot.2016.07.002

Wardle DA, Bardgett RD, Callaway RM, Van der Putten WH (2011) Terrestrial ecosystem responses to species gains and losses. Science 332: 1273-1277. https://doi.org/10.1126/ science. 1197479

\section{Supplementary material I}

A. Association between health of pines and response by $S$. noctilio and $S$. nigricornis; B. Emergence of $S$. noctilio and $S$. nigricornis from pines collected from New York and Pennsylvania in spring 2012

Authors: Ann E. Hajek, Jacob C. Henry, Christopher R. Standley, Christopher J. Foelker Data type: Microsoft Word Document (.docx)

Copyright notice: This dataset is made available under the Open Database License (http://opendatacommons.org/licenses/odbl/1.0/). The Open Database License $(\mathrm{ODbL})$ is a license agreement intended to allow users to freely share, modify, and use this Dataset while maintaining this same freedom for others, provided that the original source and author(s) are credited.

Link: https://doi.org/10.3897/neobiota.36.14953.suppl1 